\title{
Chemical composition of different fractions of Solanum lycocarpum St Hil
}

H R Lima Neto, A S Chaudhry, M M H Khan

Newcastle University, Newcastle, United Kingdom

Email:helio.limaneto@gmail.com

Introduction Globally methane released from the rumen represents approximately a third of all anthropogenic actions and novel crops could be an alternative to tackle this problem (Beauchemin et al., 2008). In addition the development of arid resistant plants and natural products to manipulate ruminal fermentation are being speculated as part of cutting edge technologies currently under study to optimize ruminal function. In this context the wild shrub Solanum lycocarpum St Hil. could be an alternative crop as well as novel rumen manipulator agent. Here its chemical composition is presented as part of a project which has been investigating the use of some fractions of this plant as a potential animal feedstuff.

Materials and methods Five dried meal-like fractions of Solanum lycocarpum (SL) (Flower=Fl, Fruit=Fr, Leaf=Lf, Stem= St and Root=Rt) from two different seasons (wet/summer - between January/March and dry/winter - between July/ September of 2008) from Brazil were analysed in triplicates for their Crude Protein (CP), Ether Extract (EE), Total Sugar(TS) and Starch (ST), Total Phenols(TP), Tannins (TN) and Saponins (SP). Samples were gathered in the afternoon, sliced in small parts and spread under shadow for about 48 hours to reduce their moisture contents. Then the fractions were milled, oven dried at $60^{\circ} \mathrm{C}$ overnight and air transported to the UK. Proximate analysis was determined according to AOAC (1980). Phytochemicals were assayed using standard methods with little modifications. Total phenols, condensed tannins and saponins were determined by the method of Herborne (1978). The data were analyzed by using General Linear Model of Minitab to study the main effects of SL fractions and season as well as their interactions on chemical composition.

Results Mean chemical components for different fractions of Solanum lycocarpum different seasons are shown in Table 1. The main effects of SL fractions were significant for CP, TS, ST, TP and SP $(\mathrm{P}<0.05)$. Flower had the highest CP level with difference between seasons $(\mathrm{P}<0.01)$. Total sugar was higher for the stem and starch for the root $(\mathrm{P}<0.05)$. Total phenols were significantly higher in Flower and Fruits than other fractions. Saponins were higher in Fruits and Leaves but did not vary between seasons $(\mathrm{P}>0.05)$. Additionally, no significant interactions between fractions and seasons were observed $(\mathrm{P}>0.01)$ with the exception of $\mathrm{CP}$ and $\mathrm{SP}(\mathrm{P}<0.05)$.

Table 1 Chemical composition of Solanum lycocarpum fractions from two different seasons $(\mathrm{g} / 100 \mathrm{~g}){ }^{\text {** }}$

\begin{tabular}{|c|c|c|c|c|c|c|c|c|}
\hline \multirow[t]{2}{*}{ Fraction } & \multirow[t]{2}{*}{ Season } & \multirow[t]{2}{*}{$\mathrm{CP}$} & \multirow[t]{2}{*}{ EE } & \multirow[t]{2}{*}{ Total Sugar } & \multirow[t]{2}{*}{ Starch } & Total Phenols & \multirow[t]{2}{*}{ Condensed Tannins (CT) } & \multirow[t]{2}{*}{ Saponins } \\
\hline & & & & & & (GAE) & & \\
\hline \multirow[t]{2}{*}{ Flower } & $\mathrm{S}$ & 22.7 & 1.5 & 0.11 & 0.20 & 2.32 & 16.2 & 1.6 \\
\hline & W & 15.2 & 1.5 & 0.10 & 0.18 & 2.30 & 16.1 & 1.7 \\
\hline \multirow[t]{2}{*}{ Fruit } & $\mathrm{S}$ & 5.3 & 3.3 & 0.02 & 0.12 & 1.68 & 12.7 & 2.5 \\
\hline & W & 4.2 & 3.0 & 0.01 & 0.11 & 1.68 & 10.0 & 2.3 \\
\hline \multirow[t]{2}{*}{ Leaf } & S & 19.7 & 2.2 & 0.11 & 0.12 & 1.20 & 16.3 & 2.2 \\
\hline & W & 18.0 & 2.0 & 0.11 & 0.11 & 1.21 & 14.9 & 1.1 \\
\hline \multirow[t]{2}{*}{ Stem } & $\mathrm{S}$ & 4.5 & 2.5 & 0.13 & 0.14 & 0.54 & 12.4 & 1.2 \\
\hline & W & 1.2 & 2.2 & 0.12 & 0.14 & 0.52 & 11.9 & 1.1 \\
\hline \multirow[t]{2}{*}{ Root } & $\mathrm{S}$ & 5.2 & 3.0 & 0.08 & 0.22 & 0.34 & 13.2 & 0.8 \\
\hline & W & 5.0 & 2.8 & 0.07 & 0.22 & 0.33 & 13.1 & 0.5 \\
\hline SEM (fractions) & & 3.2 & 1.2 & 0.12 & 0.15 & 0.29 & 1.3 & 0.9 \\
\hline Significance & $*$ & $* *$ & & $*$ & $*$ & $* *$ & & $*$ \\
\hline
\end{tabular}

** $\mathrm{P}<0.01 ; * \mathrm{P}<0.05$ (in each of the columns, shows statistical differences between fractions); SEM (Standard error of means); $\mathrm{S}=$ Summer \& W=Winter; $\mathrm{CP}=$ Crude Protein; $\mathrm{EE}=$ Ether Extract; $\mathrm{GAE}=$ Gallic Acid Equivalent

Conclusions All fractions showed statistical differences regarding all chemical constituents with the exception of EE and CT. Secondary metabolites are present in high levels and demand further investigations to evaluate their effect on ruminal metabolism.

Acknowledgements Mr. Helio Lima is grateful to Brazilian Government by providing his CAPES Doctoral Scholarship

\section{References}

AOAC. 1980 Official methods of analysis, $13^{\text {th }}$ Ed. Association of official analytical chemists. Washington D.C. $370-400$. Beauchemin, K.A., Kreuzer, M., O’Mara, F., McAllister, T.A., 2008. Nutritional management for enteric methane abatement: a review. Australian Journal of Experimental Agriculture 48, 21-27.

Herborn, J. B. 1998. Phytochemical methods. $3^{\text {rd }}$ Edition., Chapman and Hall Ltd., London, $135-203$. 